\title{
SARAJEWSKI ELEMENTARZ MILJENKA JERGOVICIA
}

\author{
SABINA GIERGIEL 1 \\ (Opole)
}

\begin{abstract}
Słowa kluczowe: przestrzeń, historia, przedmiot, nostalgia, przeszłość
\end{abstract}
Keywords: space, history, object, nostalgia, past

\begin{abstract}
Abstrakt: Sabina Giergiel, BOŚNIACKI ELEMENTARZ MILJENKA JERGOVICIA. „PORÓWNANIA" 10, 2012, Vol. 10, s. 221-238. ISSSN 1733-165X. Artykuł koncentruje się wokół zagadnień związanych ze sposobem przedstawienia miejsca pochodzenia (tj. Sarajewa) w zbiorze Miljenka Jergovicia zatytułowanym Historijska čitanka. Opowieść o mieście staje się świadectwem istnienia świata, który uległ zagładzie i wyrazem sprzeciwu wobec manipulowania pamięcią. Miejsce, z którego pisarz pochodzi jest $\mathrm{w}$ jego ujęciu przestrzenią nieobojętną semantycznie i aksjologicznie, przepełnioną znaczeniami, które są czytelne jedynie dla niegdysiejszych mieszkańców. Elementy rzeczywistości stanowią ponadto dla nich płaszczyzną porozumienia, istniejącego pomiędzy przedstawicielami pokolenia urodzonego w latach sześćdziesiątych, których łączy identyczne doświadczenie wojny i podziału kraju oraz poczucie utraconych możliwości.
\end{abstract}

Abstract: Sabina Giergiel, SARAJEVO'S READING PRIMER BY MILJENKO JERGOVIĆ. “PORÓWNANIA" 10, 2012, Vol 10, p. 221-238. ISSN 1733-165X. The article focuses on issues connected to methods of depicting place of origin (i.e. Sarajevo) in a collection entitled Historijska čitanka. The story about the town becomes a testimony of an annihilated world and a protest against manipulating memory. In the writer's picture, his place of origin is not semantically and axiologically indifferent, it is filled with meanings understood exclusively by its former dwellers. Elements of reality are a common basis for agreement between members of the generation of people who were born in the sixties sharing identical experience of war and division of the country as well as a feeling of lost opportunities.

Fascynacja własną przeszłością, tak wyraźnie obecna w ciągu ostatnich dwudziestu lat w literaturze byłej Jugosławii, połączona z autobiografizmem i poszu-

${ }^{1}$ E-mail Address: sgiergiel@uni.opole.pl 
kiwaniem tego, co najbardziej „nasze” ma - jak się wydaje - co najmniej dwa źródła. Zabiegi tego rodzaju związane są z przemianami historyczno-społecznymi, które dotknęły te tereny oraz - pośrednio - z przemianami, jakie miały miejsce we współczesnej filozofii i antropologii. Po pierwsze ich źródeł można się doszukiwać w rozpadzie stabilnego jak dotąd porządku (wspólna ojczyzna, potem wojna, w wyniku której powstają nowe państwa), po drugie zaś są one wynikiem odejścia od wizji podmiotu jako konstruktu raz na zawsze danego, stałego i substancjalnego. Biorąc pod uwagę przemiany społeczno-polityczne, jakie dotknęły region, pisarstwo naznaczone perspektywą autobiograficzną oraz swoistym przywiązaniem do miejsca pochodzenia można odczytywać w kontekście wysiłków mających na celu upamiętnienie świata i czasu, który przeminął, jako potrzebę pozostawienia śladu; śladu, który staje się egzystencjalnym piętnem, ciążącym na pisarzach do dnia dzisiejszego.

W moim przekonaniu jednym z najciekawszych świadectw uprawniających do tego typu stwierdzeń jest twórczość Miljenka Jergovicia - pisarza pochodzącego z Bośni, ale dziś mieszkającego w Chorwacji. Chodzi mi zwłaszcza o te jego teksty, które koncentrują się na obrazie Bośni (zwłaszcza Sarajewa), a w samym centrum niniejszych rozważań znajduje się zbiór zatytułowany Historijska čitanka 1 (Historyczna czytanka/elementarz) ${ }^{2}$. Niezwykle znaczący w kontekście moich refleksji jest również esej M. Jergovicia, zatytułowany Tamo gdje žive drugi ljudi (Tam, gdzie mieszkają inni ludzie) z antologii Nepoznati susjed (Nieznany sąsiad) ${ }^{3}$. Pisarz po-

2 M. Jergović, Historijska čitanka 1. Zagreb 2008. Pierwsze wydanie zbioru pochodzi z 2001 roku. Jako ciekawostkę dodam, że na oficjalnej stronie pisarza znajduje się informacja, że tom ten składa się z opowiadań (priče) <http://www.jergovic.com/> (19.06.2011 r.). Natomiast na ostatniej stronie wydania książkowego, którym ja się w tym miejscu posługuję widnieje informacja, że książka stanowi zbiór artykułów (članci), co wydaje mi określeniem trafniejszym. Biorąc pod uwagę specyfikę takich gatunków jak artykuł i felieton, uznałam, że teksty Jergovicia pod względem genologicznym należałoby przyporządkować do tej drugiej kategorii. Zob. hasła: artykuł, felieton, publicystyka, w: Słownik terminów literackich. Red. J. Sławiński. Wrocław-Warszawa-Kraków 2000, s. 47, 151-152 i 455.

${ }^{3}$ M. Jergović, Tamo gdje žive drugi ljudi, w: R. Swartz (red.), Nepoznati susjed. Antologija s jugoistoka Europe. Zagreb 2007, s. 137-158. Warto w tym miejscu umieścić kilka informacji o samej antologii, która wydaje mi się ciekawym przyczynkiem do świadomości własnego położenia i autodefinicji intelektualistów z państw, które w ostatnich kilkudziesięciu latach zostały tak ciężko dotknięte przez historię. Teksty (oraz losy) twórców zebranych w tym tomie układają się w obraz zmagań jednostek z własną odrębnością, jak i ze świadomością wieloznaczności terenów, na jakich jej autorzy się wychowali. Redaktor antologii - Richard Swartz twierdzi, że stanowi ona ni mniej ni więcej tylko książkę z tekstami reprezentantów współczesnej prozy z terenu Południowo-Wschodniej Europy. Jak sam zauważa w końcowej części książki, jest jeszcze jeden element łączący zaprezentowanych w niej pisarzy. Otóż wielu z nich w momencie wydania antologii mieszkało już poza granicami swej ojczyzny, wiele z prezentowanych tekstów powstało na emigracji, część z nich w "nowych" językach, co dodatkowo oświetla sytuację tego regionu (warto dodać, że wedle informacji umieszczonej na końcu książki ukazała się ona jednocześnie w Albanii, Bośni i Hercegowinie, Bułgarii, Macedonii, Serbii i Słowenii). Zob. R. Swartz, Pogovor, w: Ibidem, s. 357-362. 
wraca w nim do swoich przodków, wskazując na fakt, iż w żyłach członków jego rodziny płynie krew niemiecka, słoweńska i chorwacka. Pradziadek Jergovicia był bowiem Niemcem z banackiej wsi, leżącej dziś w granicach Rumunii, który do szkół chodził w Budapeszcie i w Wiedniu, a całe swoje dorosłe życie przeżył w Bośni jako kolejarz ${ }^{4}$, zaś w czasie drugiej wojny światowej ratował przed ustaszami Serbów. Jeden z jego wnuków trafił na front i zginął tam jako niemiecki żołnierz, drugi natomiast, w związku z tym, że w szkole był jednym z niewielu katolików, świadomie został przez rodziców posłany na naukę islamu. Te wszystkie rodzinne historie, według Jergovicia, w znacznym stopniu określają jego tożsamość, będąc jej niezbywalnym elementem ${ }^{5}$. Gdy w 1993 roku pisarz opuszcza Sa-

${ }^{4}$ Niejako w tle pojawi się tutaj cień Austro-Węgier, które wśród części intelektualistów z terenów byłej Jugosławii stały się symbolem pokojowego współistnienia w różnorodności. Przywołajmy w tym miejscu obszerny cytat, niezwiązany bezpośrednio z głównym tokiem tego wywodu, ale który doskonale obrazuje dwudzielność myślenia o kulturze (i zewnętrznych wobec niej wzorach) na tych terenach. Otóż Vlado Gotovac, analizując stosunek Petara Kočicia (dziewiętnastowiecznego pisarza z Bośni, który po aneksji Bośni przez Austro-Węgry wykazywał niezwykłą wrogość wobec nowych władz, będąc jednocześnie symbolem budzenia się świadomości narodowej mieszkańców Bośni i wpływów serbskich), pisze: „W swej twórczości krytykował Austro-Węgry z pozycji osoby odrzucającej cywilizację i prawo, odcinającej się od społeczeństwa obywatelskiego, które przynosi ze sobą europejskie państwo oparte na prawnej, politycznej i państwowej tradycji współczesnego świata. W tym świecie zarówno przekonania, jak i przyzwyczajenia reprezentowane przez Kočicia są nie do przyjęcia. Jego konflikt z Austro-Węgrami polega zatem nie tylko na niechęci/sprzeciwie wobec pewnej formacji duchowej i kulturowej, ale i wobec określonego ładu państwowego, których nie da się uzgodnić z Kočicia naturalistyczno-pogańską, wewnętrznie rozbitą bizantyjską koncepcją państwa". („On se u svom djelu opirao Austro-Ugarskoj s pozicije koja odbija civilizaciju, odbija zakone, odbija strukturu civilnog društva koju donosi sa sobom jedna europska država izgrađena u skladu s pravnom, političkom i državnom tradicijom suvremenog svijeta, u kom su nazori i navike koje Kočić zastupa neodržive. On se dakle ne sukobljava s Austro-Ugarskom samo kao s određenim duhovnim, kulturnim konceptom nego i kao s određenim državnim redom koji je posve inadekvatan njegovom naturalističko-poganskom, iznutra razorenom bizantskom konceptu carstva"). Cyt. za: Ž. Ivanković, Kulturni identitet - mitsko stanje stvari, w: Tegoż, Tetoviranje identiteta. Pohlepa za prošlošću. Studije i eseji. Sarajevo 2007, s. 178-179. Na marginesie dodać należy, że mit Austro-Węgier (jak to zwykle bywa z mitem) nie do końca odpowiadał rzeczywistości. Jednak zdaje się on być dziś jedną z pozytywnych odpowiedzi na działania zmierzające do tworzenia społeczności zamkniętych i jednorodnych, odgradzających się wyraźnie od sąsiadów, odrzucających transgresyjność i podkreślających rolę granicy.

${ }^{5}$ Psychologia poznawcza i narracyjna, podkreślając niezbywalny związek łączący pamięć z tożsamością, uznaje, że pamięć nie „ożywia” ponownie przeszłych doświadczeń, lecz rekonstruuje je wychodząc od aktualnych warunków. Wspomnienia zaś nie tyle reprodukują minioną rzeczywistość, ile raczej stanowią dynamiczną formę aktualizacji doświadczeń istotnych dla danej tożsamości. Zostają bowiem dopasowane do aktualnych warunków i możliwości działania, a tym samym - niejako ex post - podlegają (często nieuświadamianej) korekcie reinterpretującej przede wszystkim kłopotliwe i nieprzyjemne doświadczenia. Zob. B. Neumann, Literatura, pamięć, tożsamość. Tłum. A. Pełka, w: M. Saryusz-Wolska (red.), Pamięć zbiorowa i kulturowa. Wspótczesna perspektywa niemiecka. Kraków 2010, s. 249-253. Istnieje zatem (prawdopodobnie nieuświadamiany) dialog wspominającego z jego dawnym Ja, na mocy którego dochodzi do swoistego dopasowania tych dwu nietożsamych ze sobą aspek- 
rajewo, przenosząc się do Chorwacji, zdaje sobie sprawę, że wyjeżdża do kraju swego języka, ale zawsze pozostanie w nim Innym, o czym zresztą dobitnie świadczy przywołany przez pisarza epizod, jaki miał miejsce podczas festiwalu filmowego organizowanego na Istrii. Wtedy to, prawdopodobnie w związku z krytycznym artykułem, jaki Jergović opublikował $\mathrm{w}$ jednej $\mathrm{z}$ chorwackich gazet na temat zarządzania kulturą przez ówczesnego ministra, usłyszał następujące słowa: „Won stąd, ty bośniacki śmieciu, wracaj tam, skąd przyjechałeś, żebyśmy nie musieli ci w tym pomóc!"6. Zwielokrotniona tożsamość pisarza, brak możliwości jednoznacznego przyporządkowania, skutkuje zatem wyraźną próbą wyrzucenia go poza ramy wspólnoty, co bezpośrednio zostaje wyartykułowane $\mathrm{w}$ obraźliwych i zawierających groźbę słowach ${ }^{7}$. Są one odpowiedzią (oczywiście niemerytoryczną) - jak zauważa sam twórca - na jego krytyczny tekst, ale zawierają się w nich te elementy jego tożsamości, którymi można Jergovicia w pewnym sensie zdyskredytować, naznaczyć i wykluczyć, które nie pozwalają zredukować jego osoby do pożądanej, jednolitej formy. Ale jednocześnie te słowa zmuszają ich adresata do refleksji nad własną najgłębszą istotą, determinują autonomicznie podejmowane wysiłki zmierzające do wyzwolenia się spod presji ogółu, co - jak sądzę - prowadzić może do uświadomienia sobie, kim tak naprawdę jestem i doświadczenia samego siebie.

Obcość, stanowiąca doświadczenie odróżniające, a zarazem dystansujące Jergovicia od Chorwatów ma swoje źródło w miejscu (przestrzeni geograficznej, niosącej ze sobą wielorakie konotacje), z którego pochodzi. Dzieciństwo i młodość spędzona w Bośni stanowią doświadczenia niemożliwe do przekazania, doświadczenia konstytutywne i nieprzekładalne. Gra asocjacji w pewnym momencie prowadzi narratora felietonów od wspomnień oglądanych w dzieciństwie bajek i reklam (wypełnionych kierowanymi do dzieci deminutywami) do swoistego poczucia wykluczenia, z grupy Chorwatów, którzy - jak mi się wydaje - z poczuciem wyższości używają zdrobnienia na określenie bośniackich muzułmanów. Przywołajmy w tym miejscu odpowiedni fragment:

tów jednostki. Tego rodzaju uwagi ściśle powiązane są z rozważaniami Paula Ricoeura, który dyskursywnie opracował koncepcję bycia sobą w czasie. Zob. P. Ricoeur, Filozofia osoby. Tłum. M. Frankiewicz. Kraków 1992, a zwłaszcza P. Ricoeur, O sobie samym jako innym. Tłum. B. Chełstowski. Naukowo opracowała i wstępem opatrzyła M. Kowalska. Warszawa 2003.

${ }^{6}$ „Marš, smeće jedno bosansko, idi tamo odakle si i došao, da te mi ne bi tamo vraćali!” M. Jergović, Tamo gdje..., op. cit., s. 147.

7 Mamy tu do czynienia z systemem wykluczenia, który Michael Foucault łączy z dystansowaniem się jednostki od obowiązującego dyskursu i systemu produkcji symboli. Zob. M. Foucault, Szaleństwo i społeczeństwo, w: Tegoż Filozofia. Historia. Polityka. Wybór pism. Tłum. i wstęp D. Leszczyński i L. Rasiński. Warszawa-Wrocław 2000, s. 84-85. Jergović wypowiadając się krytycznie o rządach jednego z Ministrów w pewnym sensie narusza społeczne tabu. Ponadto swoją opinią podważa powszechnie obowiązujące przekonanie, że po otoczonym złą sławą okresie istnienia Chorwacji w ramach wspólnoty jugosłowiańskiej przyszedł czas, w którym wszystko to, co dzieje się, bliskie jest ideałowi. 
Wiele lat później, gdy już dorośnie [on, tj. chłopiec, przyszły pisarz, a zatem sam Jergović, o którym tutaj mówi się w trzeciej osobie - S.G.] los rzuci go do miasta, w którym rzeczowników używa się w formie deminutywnej. Nawet tego rzeczownika, który służy do określenia grupy i zbioru jego przyjaciół. Rzeczownik muzułmaniątka (muslići). Brzmiał on przerażająco, bo to była jesień 1993 r. Większość muzułmaniątek, o których mówiono była wtedy otoczona drutem kolczastym. Nikt za to nie wspominał o miejscowości, w której się znajdowali. I tak nazwa tego miejsca nie miała zdrobnienia. Dretalj nigdy nie stał się Dreteljčiciem. Słowo to wypowiada się tylko w krajach, w których nie używa się zdrobnień ${ }^{8}$.

Bożena Karwowska, rozpatrując strategie charakterystyczne dla emigranckiej egzystencji Czesława Miłosza uznaje, że „swój kraj” symbolizowany przez współistnienie kultur pozwala pisarzowi na stworzenie tożsamości wielowarstwowej ${ }^{9}$. Wydaje mi się, że bez względu na zewnętrzne różnice, które rzucają się w oczy przy próbie porównania sytuacji Cz. Miłosza i Jergovicia, ich konstytucja duchowa - w sposób ontyczny związana z miejscem pochodzenia - jest bardzo podobna. Badaczka zauważa, że dla wielowarstwowej tożsamości Miłosza istnienie „innego" jest podstawą możliwości określenia samego siebie. Eliminacja „innego” musi więc prowadzić do kryzysu własnej tożsamości10, o czym przecież w sposób dobitny wspomina Jergović w cytowanym eseju. W wielowarstwowej tożsamości pisarza prymat ma zdecydowanie jednak komponent bośniacki, o czym zresztą świadczy następujący fragment wypowiedzi twórcy:

Może historia nas wyroluje i wszystko sprowadzi się do wyboru reprezentacji, w której grasz. A to jest zło nie tyle polityczne, co kulturowe. Przynależeć wyłącznie do jednego. Ale jeśli kiedykolwiek tak się stanie [...], to trzeba będzie całkiem spokojnie, bez nerwów i poczucia, że się kogoś oszukuje i zdradza wybrać swoją drużynę. Kurczę, moja jest bośniacka ${ }^{11}$.

W kontekście nowych tendencji literaturoznawczych, które nacisk kładą na obecność przestrzeni (w wielorakich jej wymiarach) w dziele literackim, mówi się

8 „Puno godina kasnije, kad već sasvim odraste, život će ga odvesti u grad gdje se sve imenice govore u deminutivima. Čak i imenica koja je u grupu i gomilu okupljala njegove prijatelje. Imenica muslići. Ta imenica zvučala je grozno jer je bila jesen 1993. Većina muslića o kojima se govorilo bili su okruženi bodljikavom žicom. Nitko nije spominjao mjesto na kojem su muslići bili u žici. To mjesto je tako ostalo bez deminutiva. Dretalj nikad nije bio Dreteljčić. Ta se riječ izgovara samo u krajevima u kojima nema deminutiva". M. Jergović, Historijska čitanka, op. cit., s. 56.

9 Zob. B. Karwowska, Tożsamość postmigracyjna - przypadek (między innymi) Czesława Miłosza. „Przegląd Humanistyczny" 2005, nr 4, s. 8.

${ }^{10}$ Ibidem.

11 „Historija će nas možda i zajebati, pa će se sve svesti na izbor reprezentacije u kojoj igraš. To nije političko, ali je kulturno zlo. Pripadati samo jednome. Ali ako se to i dogodi [...] tada treba savršeno mirno, bez sekiracije i osjećanja da nekoga ili nešto varaš i izdaješ, odabrati svoj tim. Jebi ga, moj je bosanski". M. Jergović, Historijska čitanka, op. cit., s. 18. 
o nowym regionalizmie. Biorąc pod uwagę tego rodzaju literaturę Elżbieta Rybicka zauważa, że „Lokalne czy regionalne narracje traktuje się (...) jako strategię emancypacyjną i krytyczną odpowiedź na Wielkie Opowieści Narodowościowe z jednej strony, a z drugiej jako reakcję na globalizacyjne atopie i nie-miejsca"12. Jestem skłonna uznać, że wszystkie wymienione aspekty obecne są w twórczości Jergovicia. Sposób widzenia własnej historii, ale też historii miejsca, z którego się wywodzi jest $\mathrm{w}$ pewnym sensie alternatywny zarówno wobec oficjalnych przekazów, których - o czym należy przypomnieć - kształt i sens zmieniały się w czasie, ale i wobec tych jednostek, które ze swoich osobistych losów starają się wymazać/przekreślić/przeinaczyć swój „epizod” bośniacki¹3.

Felietony zebrane w tomie Historijska čitanka łączy nie tyle perspektywa osobista, ile raczej przestrzeń geograficzna. Teksty te bowiem w pierwszym rzędzie poświęcone są Sarajewu, to właśnie miasto jest głównym bohaterem tomu, a na jego tle przedstawione zostają osobiste doświadczenia, a dokładnie przedstawiona zostaje - jak pisze autor - sentymentalna historia pewnej generacji14, pokolenia, urodzonego w latach sześćdziesiątych, które nie przeżyło żadnej rewolucji, któremu nie było dane poczuć, że ziścił się któryś z kolektywnych snów; pokolenia, które przeżyło wybuch i zakończenie wojny. Jergović w pewnym sensie uznaje siebie samego i swoich rówieśników za przedstawicieli straconej generacji, na których młodość nie przypadł moment żadnej spektakularnej zmiany znamionującej postęp czy rozwój. Co więcej, wedle pisarza przedstawicielom tego pokolenia pozostaje jedynie „zapośredniczona” tęsknota za czasami, w których ich rodzice spełniali swe własne marzenia. Tęsknota ta jest "zapośredniczona" z tego względu, że wszystkie epizody z przeszłości, które dziś wywołują w rówieśnikach Jergovicia przypływ nostalgii i tkliwości miały miejsce pięć minut przed ich narodzinami ${ }^{15}$. Symbolem straconej szansy, dowodem na to, że urodzonych $\mathrm{w}$ latach sześćdziesiątych mieszkańców Sarajewa ominęły wydarzenia wskazujące na fakt, iż świat posuwa się do przodu jest wspominany w innym miejscu automat $\mathrm{z}$ cocacolą, zainstalowany w 1984 r. w budynku Radia i Telewizji Sarajewo. Otóż gdy narrator dorósł na tyle, by móc samemu wejść do budynku i kupić wymarzoną puszkę, automat już od dawna stał zepsuty i bezużyteczny. Wojna dzieli życie dzisiejszych czterdziestolatków na dwie części. Jak mówi Jergović:

12 E. Rybicka, Od poetyki przestrzeni do poetyki miejsca. „Teksty Drugie” 2008, nr 4, s. 27.

13 Jergović przywołuje w tym kontekście nazwiska pisarzy, którzy w latach dziewięćdziesiątych jasno określili się przeciwko Miastu, wspólnocie, części własnej biografii. Zob. Historijska čitanka, op. cit., s. 19.

14 Ibidem, s. 30.

${ }^{15}$ Zob. Ibidem, s. 77. Doświadczenia opisane przez Jergovicia ze sporym prawdopodobieństwem są też doświadczeniami Aleksandra Hemona. Jergović urodził się w 1966 r, A. Hemon zaś w 1964 r. Obaj też wyjeżdżają z Bośni na początku lat dziewięćdziesiątych, choć w nieco innych okolicznościach. Hemon w 1992 r. trafił do Ameryki i tam pozostał, gdy wybuchła wojna. Jergović zaś ma za sobą doświadczenie życia w oblężonym Sarajewie, które opuszcza w 1993 r. 
[...] w tym 1991 r. zakończyła się nasza historia, a rozpoczął jakiś nowy okres, w którym uświadomiliśmy sobie gorzką prawdę, że nigdy nie podbijemy świata [...]. Nigdy nie będziemy rządzić, nigdy całkowicie nie dorośniemy i już nigdy nie będziemy żyć w czasie, który należy do nas. Nasz czas wyskoczył ze swych kolein i przemknął gdzieś obok nas. W miejsce, w którym są ci wszyscy ludzie, którzy umarli razem z nim¹6.

Sarajewo z istniejącymi na mapie miasta miejscami-symbolami jest swoistą podstawą pamiętania, a same elementy przestrzeni (opisane w zbiorze Historijska čitanka 1) stają się pretekstem do snucia rozważań na temat czasowości. Nieobojętna semantycznie i aksjologicznie przestrzeń jest rodzajem podpory dla pamięci; przedmioty, ulice, niezwykłe osoby wpisane w krajobraz miasta, budynki, tworzą przestrzenne ramy pamięci, ona to bowiem potrzebuje miejsc i ulega uprzestrzennieniu. Zagadnieniu związku przestrzeni i pamięci poświęcił swój tekst Jan Assman, który pisząc o krajobrazie (w interesującym mnie przypadku będzie to nie tyle krajobraz kojarzony z przyrodą, ile raczej przestrzeń miejska) zauważa, że nawet one, tj. całe krajobrazy służą jako medium pamięci kulturowej, poprzez podniesienie ich do rangi znaku, a więc za sprawą ich semiotyzacji. Krajobraz/ /miasto zatem stać się może topograficznym „tekstem” pamięci kulturowej, czyli mnemotoposem (tj. miejscem pamięci właśnie) ${ }^{17}$.

Mitologizacja codzienności związana z elementami kultury materialnej ma niejednoznaczny charakter. Uwznioślanie przedmiotów trywialnych, które stają się znakami niewyrażalnego, może bowiem skutkować niezamierzonym komizmem. Inaczej rzecz się ma w narracji, która - jak się wydaje - celowo przez pisarza poddawana jest jednocześnie zabiegom mitologizacji i demitologizacji. Taki charakter ma obecna na wielu planach ironia i autoironia, która dodatkowo zabarwia świat przedstawiony wczesnych utworów Jergovicia. Można w tym miejscu zacytować słowa Ewy Wiegandt, która opisując powieść o galicyjskim dzieciństwie twierdzi, iż:

[...] dorosły podmiot jawnie mitologizuje swe dzieciństwo, świadom nieadekwatności i nieautentyczności swych poczynań. Budując mity, jednocześnie je dezawuuje, albowiem podane w otoczce wyżej przytoczonych zabiegów stylizacyjnych [autorka ma na myśli stylizacje biblijne, antyczne, odwołania do stylów naukowych czy stylów literacko spetryfikowanych - S.G], osiągają efekty komiczne, bardzo bliskie mechanizmowi komizmu właściwemu parodii czy trawestacji heroicznej ${ }^{18}$.

$16, \ldots[\ldots]$ te 1991. svršena je naša povijest i započelo je neko novo vrijeme, ono vrijeme u kojem ćemo postati gorko svijesni kako nikada nećemo osvojiti svijet [...] Mi nikada nećemo vladati, nikada nećemo doista odrasti i više nikada nećemo živjeti u svom vremenu. Naše vrijeme je iskočilo iz zgloba i otišlo nekamo mimo nas. Otišlo je tamo gdje su svi oni ljudi koji su umrli zajedno s njim”'. Ibidem, s. 93.

17 Zob. J. Assman, Kultura pamięci. Tłum. A. Kryczyńska-Pham, w: Pamięć kulturowa..., op. cit., s. 59-99.

18 E. Wiegandt, Austria Feliks czyli o micie Galicji w polskiej prozie wspótczesnej. Poznań 1997, s. 50. 
Sarajewo zresztą, któremu tyle miejsca poświęcił pisarz w swoich utworach, w felietonach pojawia się jako samotna (ale i zdecydowanie odrębna) wyspa na mapie całej Jugosławii. Swoją odmienność mieszkańcy Sarajewa (zatem i Jergović) fundują na specyficznej egzystencji miasta, z którego pochodzą. Stolicy jednej $\mathrm{z}$ republik, która zawsze sytuowała się w opozycji wobec stolic pozostałych administracyjnych części Jugosławii, której Sarajewianie na przemian wstydzili się lub z której byli dumni. Ich tożsamość (rozumiana jako pewna kolektywna własność), podobnie jak $w$ przypadku jednostkowym, kształtowała się zatem na przecięciu własnego wyobrażenia o sobie i obrazu, jaki skonstruowali inni. Swoiste poczucie niższości, w którym spotyka się przekonanie wytworzone na miejscu z obrazem Bośniaków przechowywanym $\mathrm{w}$ świadomości mieszkańców innych republik (zwłaszcza Chorwacji i Serbii), charakteryzuje sytuację istnienia na pograniczu.

Pogranicze, pozostając $\mathrm{w}$ kręgu oddziaływania wielu centrów, zawsze będzie $\mathrm{z}$ ich perspektywy - peryferią. Egzotyczną prowincją, folklorystycznym skansenem, przyczółkiem bądź przedmurzem, w zależności od tego, jaka ideologiczna moda zawładnie świadomością centrum ${ }^{19}$

- pisze Maria Dąbrowska-Partyka. O kompleksie Sarajewa wobec innych „metropolii" ówczesnej Jugosławii dobitnie świadczy następujący fragment:

W latach osiemdziesiątych Sarajewo również na polu kultury, a nie tylko piłki nożnej dorównało Jugosławii. Choć tak naprawdę dorównywało jej zawsze, ale kompleks niższości wobec Belgradu i Zagrzebia był tak wielki, że musiałeś być wzrostu Rašy Radovanovicia, by poczuć się wyższym od jakiegoś mieszkańca Belgradu, który potrzebował drabiny, by wspiąć się na krawężnik ${ }^{20}$.

By wskazać na specyfikę Bośni pisarz przywołuje powszechnie znane tezy Iva Andricia ${ }^{21}$ i mniej znane konkluzje Stevana Tonticia. Kraj ten w ich ujęciu to zatem miejsce znajdujące się ",[...] w płytkiej Europie i głębokiej Azji [...], ten kraj pokazuje w co zmienia się raj, gdy utraci kontekst. Bośnia więc była rajem pozbawionym kontekstu, automatem z Coca-Colą bez Coca-Coli" 22 .

19 M. Dąbrowska-Partyka, Pogranicze - konflikt i synteza kultur, w: Tejże, Literatura pogranicza. Pogranicza literatury. Kraków 2004, s. 35.

20 "Osamdesetih godina Sarajevo je dostiglo Jugoslaviju i u kulturi, a ne samo u nogometu. Zapravo, dostizalo ju je uvijek, ali je kompleks manje vrijednosti pred Beogradom i Zagrebom u Sarajlija bio tolik da si morao biti visok kao Rašo Radovanović da bi se osjećao višim od nekog Beograđanina kojem trebaju ljestve da se popne na trotuar". M. Jergović, Historijska čitanka, op. cit., s. 44.

${ }^{21} \mathrm{O}$ Andricia widzeniu Bośni wyczerpująco pisze M. Dąbrowska-Partyka w tekście zatytułowanym Ivo Andrić albo paradoksy pogranicza, w: Tejże, Literatura pogranicza...., op. cit., s. 69-81.

22, , $[. .$.$] u plitkoj Europi i dubokoj Aziji [...], ta zemlja potvrđuje u šta se pretvara raj kada zgubi$ kontekst. Bosna je, eto, bila raj bez konteksta, automat za Coca-Colu bez Coca-Cole". M. Jergović, Historijska čitanka, op. cit., s. 76. 
Bośnia to również kraj, który tworzyli urzędnicy przybywający z różnych krańców Austro-Węgier. O tym epizodzie w jej historii Jergović mówi w następujący sposób:

Wraz z Austrią do Bośni ze wszystkich stron Monarchii przybyli kuferasze. Dla tych biedaków Bośnia była zarówno ziemią obiecaną, jak i karą za ich nędzę. Umierali, a na ich grobach stawiano pomniki, na których wyryte były dziwne, gotyckie, niemieckie napisy, które do dziś przywołują jakiś inny lepszy los. Przywołują ich małe ojczyzny, z których za karę przybywali do Sarajewa ${ }^{23}$.

Warto zauważyć, że Bośnia w twórczości wielu pisarzy z tym terenem związanych nigdy nie jest przestrzenią „obojętną" semantycznie. Kraj ten posiada własną specyfikę, odróżniającą go od innych państw powstałych po rozpadzie Jugosławii. Dla Jergovicia jest obszarem pogranicznym, miejscem na końcu świata, w którym mieszają się (a może lepiej powiedzieć mieszały się) różnorodne komponenty etniczne i kulturowe, tworząc nową jakość. Jest przestrzenią, której wykreowany $\mathrm{w}$ literaturze obraz posiada cechy przypisywane kresom w polskiej (powojennej ${ }^{24}$ ) literaturze, na których „dzięki poszanowaniu dla Innego wszyscy byli różni, lecz zarazem każdy był swój: «małe ojczyzny» zamieszkiwali bowiem ludzie, którzy wiązali tożsamość z regionem, a nie z państwem, nacją czy religią"25. Bośnia to także miejsce, do którego w przeszłości trafiano „za karę”, w którym dominuje nieustanny ruch i zmiana, spowodowana dopływem nowych mieszkańców. Tyle tylko, że kiedyś - w odległym 1878 r. - przybysze ze swoim dobytkiem trafiali do Sarajewa z Wiednia, Zagrzebia i Bratysławy. W 1992 r. zaś przybywano z Srebrenicy, Wyszehradu i Nowego Pazaru bez bagaży. Historia zatem nieustannie zatacza krąg, stolicę Bośni określa ciągły ruch, a różnica pomiędzy przybyszami z końca XIX i XX wieku sprowadza się do ich imion, języka, rodzaju kary i wygnania, jakie stały się ich udziałem ${ }^{26}$.

Aktualne przemiany, które dotknęły samych podstaw dyskursu naukowego, dotyczą między innymi pojmowania historii, która przestaje być uznawana za wiedzę obiektywną. Skoro zatem w historii człowiek nie może już znaleźć prawdy

23 "S Austrijom su došli kuferaši iz svih delova Monarhije. Bosna je za tu sirotinju bila obećana zemlja i Bosnom su bili kažnjeni zbog svoga siromaštva. Umirali su i sahranjivani su pod spomenicima na kojima su stajali čudni gotički, njemački natpisi koji do danas prizivaju neku drugu, bolju i sretniju sudbinu. Prizivaju one zavičaje iz kojih se po kazni dolazilo u Sarajewo". Ibidem, s. 158.

24 Przemysław Czapliński wskazując na pisarzy, którzy ów konwencjonalny, idealizowany obraz utrwalili przywołuje Juliana Stryjkowskiego, Tadeusza Konwickiego, Andrzeja Kuśniewicza i Leona Buczkowskiego. Przeciwstawia tę twórczość tekstom z lat dziewięćdziesiątych, w których widać wyraźnie przemianę obrazu "małych ojczyzn”. Zob. P. Czapliński, Mapa, córka nostalgii, w: Tegoż, Wzniosłe tęsknoty. Nostalgie w prozie lat dziewięćdziesiątych. Kraków 2001, s. 105-128.

25 Ibidem, s. 106.

26 Zob. M. Jergović, Historijska čitanka, op. cit., s. 159. 
(dodać wypada, że w tym wypadku też prawdy o sobie), to przestaje ona być gwarantem wyjątkowości jednostki i znajduje się $\mathrm{w}$ tym, co zostało zapamiętane, w drobnych elementach rzeczywistości, wspomnieniach, przedmiotach, niejednokrotnie zapachach, słowach, miejscach. Ryszard Nycz, który swoje interpretacje polskiej literatury współczesnej podporządkował pojęciu epifanii zauważa, iż rzeczom, elementom realności dana jest możliwość wskazywania na metafizyczną stronę rzeczywistości, ukrytą niejako za fasadą świata. Rozważania te pośrednio mają swoje źródło w przekonaniu twórców, że słowa są bezradne wobec tego wszystkiego, co pisarz chciałby wyrazić. Prawda zaś, która nie poddaje się obiektywnemu odtworzeniu, dostępna jest tylko w ramach subiektywnego, wewnętrznego aktu doświadczającego podmiotu. Epifanijność oznacza w tym ujęciu nagłe doznanie integralności, sensowności i autentyczności bycia, które niejednokrotnie pojawia się $\mathrm{w}$ związku z banalnymi rzeczami, wydarzeniami czy przeżyciami ${ }^{27}$. Przedmiotu $\mathrm{w}$ literaturze nie należy utożsamiać z przedmiotem fizycznym czy idealnym - jak w innym miejscu pisze badacz. To raczej

literacko-kulturowy konstrukt przedmiotu jako „wielowarstwowego konkretu”; wielowarstwowego, bo wpisanego w ludzką historię i kulturę, przez człowieka przeżytego i doświadczanego, przenikniętego więc znaczeniami, wartościami, które stanowią o jego kulturowej naturze ${ }^{28}$.

W epifanijnym błysku dotkliwie doświadczyć można tego, co przeminęło. Bowiem - jak powiada Walter Benjamin - „przeszłość uchwycić można tylko jako obraz, który w chwili swej rozpoznawalności właśnie rozbłyska na wieczne pożegnanie" 29 .

Charakter swoistej epifanii ma - w moim przekonaniu - obecne zwłaszcza w utworach pisarzy pochodzących z Bośni, obsesyjne powracanie do przedmiotów, zabaw dziecięcych czy miejskich bohaterów i związanych z nimi przeżyć (często mających charakter wspólnego doświadczenia pokoleniowego dla przed-

27 Zob. R. Nycz, Literatura jako trop rzeczywistości. Poetyka epifanii w nowoczesnej literaturze polskiej. Kraków 2001. Zob. zwłaszcza rozdział "Wyrażanie niewyrażalnego" w literaturze nowoczesnej (wybrane zagadnienia) oraz "Zamknięty odprysk świata”. O pisarstwie Gustawa Herlinga-Grudzińskiego, s. 18-49 i $208-220$.

${ }^{28}$ R. Nycz, Wprowadzenie. Kulturowa natura, staby profesjonalizm. Kilka uwag o przedmiocie poznania literackiego i statusie dyskursu literaturoznawczego, w: Tenże i M. P. Markowski (red.), Kulturowa teoria literatury. Główne pojęcia i problemy. Kraków 2002, s. 20. Moje rozumienie przedmiotu jest tu niezwykle szerokie. Przedmiotem jest dla mnie zarówno rzecz, jak i inne elementy rzeczywistości, które - poprzez opis - zostają przedstawione/uobecnione w tekście literackim. Pozwala mi to na uznawanie, iż nie tylko rzeczy, ale i rytuały, idole, zdarzenia związane z Bośnią, które przywołuje w swoich utworach Jergović są wypełnione znaczeniami i wartościami.

29 W. Benjamin, O pojęciu historii. Tłum. K. Krzemieniowa, w: Tegoż, Anioł historii: eseje, szkice, fragmenty. Fragmenty, wybór i oprac. H. Orłowski. Tłum. K. Krzemieniowa i inni. Poznań 1996. Tekst ze strony: <http://strebski.dyktatura.info/wp-content/texts/philosophy/Benjamin01.pdf> (12.11.2010 r.) 
stawicieli wszystkich byłych republik), pochodzących z dzieciństwa czy wczesnej młodości. Przedmioty, często banalne i nic nie znaczące poza kontekstem, wskazują na pewien porządek istniejący niejako ponad nimi. Są one emblematami, symbolami czasu młodości, czasu w pewnym sensie idealnego, który z dzisiejszej perspektywy (człowieka dorosłego, który zdaje sobie sprawę z utraconej wspólnoty) był okresem szczęścia i niewinności. Są to często przedmioty bliskie, oswojone, które przywołują świat już nieistniejący ${ }^{30}$, odsyłają do czasu i pewnej przestrzeni, działając na zasadzie metonimii ${ }^{31}$. Można powiedzieć, że te "odpryski” rzeczywistości są swoistymi nośnikami pamięci, w rozumieniu Marcina Kuli, który twierdzi: „Przeszłość odzwierciedla się [...] praktycznie w każdym przedmiocie i zjawisku, które trwa do dziś. W konsekwencji nośnikiem pamięci o przeszłości, przynajmniej potencjalnym, jest dosłownie wszystko"32. To „wszystko" staje się jednak podporą pamięci jedynie wtedy, jeśli zostaje wyposażone w indywidualną pieczęć; rzecz istniejąca sama w sobie nic nie znaczy, jest niejako neutralna, dopiero $\mathrm{w}$ momencie, w którym dochodzi do przecięcia się materialnego przedmiotu

30 Podobną funkcję spełnia projekt, który początkowo ograniczał się do Internetu, a którego efektem było wydanie obszernej książki Leksikon $Y u$ mitologije, stanowiący swoisty katalog zjawisk, przedmiotów, przejawów kultury pozbawiony ideologicznego zaplecza. Leksykon zawiera hasła rozpoznawalne dla większości mieszkańców tego terenu, symbolicznie zakreślając przestrzeń wspólnoty. Wydany został wspólnymi siłami przez zagrzebskie - Postscriptum i belgradzkie wydawnictwo - Rende. Hasła zamieszczone w leksykonie początkowo trafiały na stronę internetową, która stanowiła wspólną "własność” byłych Jugosłowian. O demokratycznym charakterze projektu świadczy fakt, iż wśród autorów haseł znajdują się zarówno uznane autorytety z owych terenów (Ivan Čolović czy znani dziennikarze tygodnika „Vreme”), jak i zwykli, często anonimowi obywatele Jugosławii. Zob. I. Adrić, V. Arsenijević, Đ. Matić (red.), Leksikon Yu mitologie. Beograd-Zagreb 2004. Pomysł na stworzenie swoistego katalogu elementów ze wspólnej przeszłości pojawia się także w powieści Dubravki Ugrešić, Ministerstwo Bólu. Tłum. D.J. Ćirlić. Izabelin 2006. Pierre Nora, francuski badacz zajmujący się relacjami zachodzącymi pomiędzy pamięcią a historią, diagnozując sytuację współczesną zauważa, że naszą epokę dotyka „obsesja archiwum, które pragnie jednocześnie całkowitej konserwacji teraźniejszości i absolutnego ocalenia przeszłości. (...) Pamięć została całkowicie pochłonięta przez drobiazgowe próby jej odtworzenia. Jej nowym powołaniem jest rejestrowanie; zrzucając na archiwum odpowiedzialność za pamiętanie, zrzucamy tam swoje znaki tak, jak wąż zrzuca swą skórę". P. Nora, Między pamięcią i historią: Les lieux de Memoire. Tłum. P. Mościcki, w: A. Leśniak, M. Ziółkowska (red.), Tytuł roboczy: archiwum. Łódź 2009, s. 7. Cytowane słowa Nory nie mają bezpośredniego związku z moimi wcześniejszymi rozważaniami, są jednak ciekawym przyczynkiem do rozważań na temat kondycji współczesnego świata.

31 O metonimicznym charakterze zdolności przedmiotu, który będąc znakiem ludzkiej rzeczywistości odsyła do swego właściciela lub wytwórcy, pisze Bogumiła Kaniewska w tekście Postać literacka w estetycznym uniwersum, w: S. Wysłouch i B. Kaniewska (red.), Człowiek i rzecz. O problemach reifikacji $w$ literaturze, filozofii i sztuce. Poznań 1999, s. 84. Jednak w interesującym mnie przypadku ważny jest nie tyle przywoływany, za pośrednictwem rzeczy, człowiek, ile raczej czas i przestrzeń (przede wszystkim pojmowana w aspekcie kulturowym) oraz pewne związane z nią wartości.

32 M. Kula, Nośniki pamięci historycznej. Warszawa 2002, s. 7-8, cyt. za: M. Saryusz-Wolska, op. cit., s. 35 . 
z wrażeniem, jakie ewokuje, traci on swe obiektywne znaczenie. Tę zależność zauważają badacze pamięci, twierdząc, że zakupiony na pchlim targu album z fotografiami ${ }^{33}$ jest semantycznie neutralny dopóki nie zostanie wyposażony $\mathrm{w}$ znaczenia, równoznaczne $z$ poznawaniem przeszłości miejsc i osób na zdjęciach uwiecznionych. Obiekty materialne bowiem przeistaczają się w medialne (w znaczeniu przedmiotu jako medium pamięci - podr. S.G.) cues dopiero po uzupełnieniu ich o opowieści ${ }^{34}$. Doskonałym dowodem na prawdziwość tego rodzaju stwierdzeń jest przywoływany już tutaj automat z coca-colą, stojący w budynku Telewizji w Sarajewie. Bez obudowania tego "przedmiotu” znaczeniem, bez symbolicznego jego przedstawienia jest on tylko jednym $\mathrm{z}$ wielu automatów, które w latach osiemdziesiątych pojawiły się zapewne we wszystkich republikach byłej Jugosławii. Opowieść Jergovicia zaś sprawia, że przestaje on istnieć jako neutralny znaczeniowo element rzeczywistości, stając się metonimią pewnego czasu, miejsca, a także doświadczeń, jakie stały się udziałem młodych mieszkańców Sarajewa.

W felietonach Jergovicia obok Wielkiej Historii (ważnej nie tyle ze względu na nią samą, ile raczej na wpływ, jaki wywarła na bohaterów) pojawiają się historie "małe", intymne, pomijane przez oficjalne przekazy. Jergović jest w swym pisarstwie podobny do kronikarza W. Benjamina, „który snuje opowieści o zdarzeniach, nie odróżniając wielkich od małych, oddaje sprawiedliwość prawdzie, że niczego, co się kiedykolwiek zdarzyło, nie należy spisywać na straty"35. Można w tym miejscu rozważać dlaczego - wedle Benjamina - nieuprawnione jest autorytarne dzielenie wydarzeń z przeszłości na znaczące i niezasługujące na uwagę. Mając na względzie refleksje Jergovicia odpowiedzieć by można, że tego rodzaju klasyfikowanie wydarzeń czy elementów świata nigdy nie jest obiektywne, nie można go zweryfikować. Bowiem jednostka czy to wskutek zapomnienia, wybiórczego charakteru pamięci czy też podświadomego wyparcia "wyciąga"

${ }^{33}$ Niezwykle znaczące $\mathrm{w}$ tym kontekście są słowa Jergovicia, którymi rozpoczyna interesujący mnie tom. We wstępie mówi o swoim zbiorze jako o inwentarzu, swoistym spisie, na który składają się elementy tworzące przeszłość miasta, czasu i państwa. W inwentarzu tym zdarzyć się mogą powtórzenia, przepełniony jest on emocjami, których powstydziłoby się każde poważne sprawozdanie z określonego czasu, ale które przepełniają albumy z fotografiami. Zbiór - jak twierdzi autor - jest bowiem właśnie takim rodzinnym albumem ze zdjęciami (podkr. S.G.). Zob. M. Jergović, Historijska čitanka, op. cit., s. 9. Nazwanie książki rodzajem albumy wydaje mi się niezwykle symptomatyczne. $Z$ tego względu, iż dokumentuje przywiązanie człowieka do fotografii, która za pośrednictwem swego rodzaju anamnezy służy do ożywiania pamięci. Album z fotografiami ponadto charakteryzuje się pewną przypadkowością, wycinkowością, ale i zdolnością do ewokowania wspomnień szerszych niż te, dotyczące tylko tego, co na zdjęciu zostało przedstawione. Oglądanie albumu sprawia, że wspomnienia napływają na zasadzie asocjacji. Te wszystkie cechy dają się odnaleźć $\mathrm{w}$ tomie Jergovicia, a samo porównanie użyte przez autora wyraźnie wskazuje na specyfikę jego tekstu.

34 Zob. A. Erll, Literatura jako medium pamięci zbiorowej. Tłum. M. Saryusz-Wolska, w: Pamięć kulturowa..., op. cit., s. 222.

${ }^{35} \mathrm{~W}$. Benjamin, op. cit. 
z przeszłości te jej elementy, które są dla niej (czasem TYLKO dla niej) istotne. Ponadto trudno z całkowitą pewnością określić co lepiej zaświadcza o danym momencie historycznym: pojawienie się w Sarajewie pierwszego automatu z cocacolą czy zimowe igrzyska olimpijskie ${ }^{36}$. Można powiedzieć, że niekonkretnie pojmowana bośniacka rzeczywistość, na którą składają się rzeczy i doświadczenia wyposażone $\mathrm{w}$ silny pierwiastek metafizyczny oraz przestrzeń, $\mathrm{z}$ unoszącym się nad nią duchem miejsca ${ }^{37}$ przejmują $\mathrm{w}$ tej literaturze symbolikę, kojarzoną $\mathrm{w}$ tradycyjnej literaturze emigrantów z domem. Tradycyjny topos domu (rozumianego jako ograniczona i wąska przestrzeń) zastąpiony zostaje przez przestrzeń szerszą: kulturową. Badaczka literatury autobiograficznej, do której zaliczyć można (z pewnymi zastrzeżeniami i dookreśleniami) przywołany tutaj zbiór Jergovicia zauważa, że toposowi domu wraz $\mathrm{z}$ uprzywilejowanymi $\mathrm{w}$ nim miejscami i przedmiotami towarzyszą inne elementy. Powieść autobiograficzna

rozwija też topos najbliższego domowi pejzażu, uwypuklający couleur locale, stwarzający poczucie bezpieczeństwa i azylu. [...] Towarzyszą [im - S.G.] dalsze: topos szkoły i przyjaźni oraz pierwszych miłosnych wzruszeń. Wszystkie [one - S.G.] nasycone są intymnością i oniryzmem, wtopione w „ludzką przestrzeń wewnętrzną" i oswojonąa

Tego rodzaju rozważania wchodzą $\mathrm{w}$ relację z coraz szerzej komentowanymi $\mathrm{w}$ literaturoznawstwie tendencjami do nadawania szczególnych znaczeń przestrzeni, zarówno tej opisanej i istniejącej niejako $\mathrm{w}$ formie fikcyjnej $\mathrm{w}$ tekście literackim, jak i tej całkowicie realnej, oznaczającej miejsce, z którego twórca pochodzi. Dodajmy, że relacje zachodzące pomiędzy oboma planami zdają się być szczególnie interesujące. Miejsce (miasto, region, dzielnica - jak uściśla Grzegorz Grochowski) zatem, opisane w literaturze, przestaje być uznawane tylko za mimetyczne odtworzenie rzeczywistości, a zaczyna być postrzegane

jako synteza rzeczy i znaczeń, jako splot tego wszystkiego, co widzialne i namacalne oraz projekcji bądź pragnień podmiotu, bądź uchwytnych jedynie pojęciowo znaczeń kulturowych i form symbolicznych [...]. Miejsca postrzegane w ten sposób tracą więc swój wymiar czysto fizykalny i anegdotyczny, a zaczynają same przypominać swoiste wypowiedzi bądź praktyki komunikacyjne ${ }^{39}$.

36 Obu wydarzeniom Jergović poświęcił osobne felietony. Trudno jednak zaprzeczyć, że informacja o pierwszym automacie z coca-colą (w odróżnieniu od informacji poświęconej sarajewskim igrzyskom) ma małe szanse na znalezienie się w oficjalnych i powszechnie akceptowanych przekazach historycznych.

37 Julian Kornhauser, próbując uchwycić specyfikę literatury bośniackiej podkreśla, iż wyznacza ją m.in. duch miejsca z jego historią i tradycją oraz pierwiastek metafizyczny. Zob. J. Kornhauser, Literatura bośniacko-hercegowińska. „Literatura na Świecie” 2003, nr 5-6, s. 275-283.

38 R. Lubas-Bartoszyńska, Od dokumentu do fikcji. Rzecz o powieści autobiograficznej, w: Tejże, Między autobiografia a literaturą. Warszawa 1993, s. 191-192.

${ }^{39}$ G. Grochowski, (Nie)widzialne miasta. „Teksty Drugie” 2008, nr 4, s. 8-9. 
Wydaje się, że przywołane stwierdzenia doskonale opisują szczególne znaczenie, jakie Bośnia (jako geograficzna a zarazem wypełniona znaczeniami przestrzeń) ma dla Jergovicia. Miejsce, z którego pisarz mówi, ma bowiem wyraźnie biograficzne, historyczne i symboliczne wymiary. Można by powiedzieć, że Jergović, w którego literaturze na równych prawach bytują bohaterowie pochodzący z wszystkich zamieszkujących Bośnię grup etnicznych ${ }^{40}$, tworzy swoistą opowieść o sobie, ale zarazem o wielu mieszkańcach tej przestrzeni, których istnieniu zagraża postulowany w tej części Europy w ostatnich dziesięcioleciach kult czystości, a ich sposób rozumienia świata ufundowany jest na dzieciństwie i przeszłości, jaką w Bośni przeżyli.

Ponadto miejsce, oglądane $\mathrm{z}$ dystansu czasowego, nabiera cech idealnych. Wiąże się to z pewnością z faktem, iż dzieciństwo i młodość zwykle jest idealizowane. Znaczenie ma tu również to, iż pokolenie, do którego należy Jergović było świadkiem zagłady miasta, jego przedstawiciele obserwowali rozpad (zarówno ten fizyczny, jak i duchowy) ich własnej przestrzeni. Przestrzeni wypełnionej lokalnymi rytuałami, regionalnymi bohaterami, powszechnie szanowanymi wariatami czy żebrakami oraz wydarzeniami, które miały znaczenie jedynie dla mieszkańców Bośni, a niejednokrotnie tylko dla mieszkańców Sarajewa. Pisarz wspominając jedną z wycieczek szkolnych i niegdysiejszy stosunek uczniów do miasta konkluduje:

Za naszymi plecami zostawało miasto, nasze drogie miasto, którego nie lubiliśmy, wobec którego byliśmy obojętni. Dokładnie tak samo jak niemowlę jest obojętne wobec własnej kołyski. O kołyskach z czułością myślą starcy, wobec swego miasta czuli są tylko ci, którzy widzieli jego śmieré ${ }^{41}$.

Powiedzieć by można, że obsesyjne wręcz powracanie przez pisarzy pochodzących z Bośni (choć nie tylko), a - podkreślmy w tym miejscu - w Bośni już niemieszkających ${ }^{42}$, ma swoje źródło również w próbie odpowiedzi na pytanie o to, kim jestem teraz; co sprawia, że jestem właśnie taki, a nie inny; co konstytuuje

\footnotetext{
40 Jergović jest bardzo płodnym pisarzem i nie sposób w tym miejscu przywołać tekstów, w których pojawia się wspomniana wyżej różnorodność. Natomiast w tym kontekście niezwykle symptomatyczny jest autorski zbiór opowiadań zatytułowany Drugi poljubac Gite Danon, w którym pisarz umieścił teksty publikowane w jego wcześniejszych książkach (z lat 1994-2006) oraz dwa nowe opowiadania. Wybór ten doskonale pokazuje, że Jergović swoim zainteresowaniem darzy zarówno Żydów, Muzułmanów, Chorwatów, jak i Serbów. Zob. M. Jergović, Drugi poljubac Gite Danon. Izabrane priče. Zagreb 2007.

41 „Iza leđa nam je ostajao grad, naš dragi jedini grad koji nismo voljeli, prema kojem smo bili ravnodušni na jednak način na koji je novorođenče ravnodušno kolijevci. O kolijevkama nježno misle starci, prema svome gradu nježni su samo oni koji su vidjeli njegovu sort". M. Jergović, Historijska čitanka, op. cit., s. 96.

42 Wydaje mi się bowiem, że swoista "obsesja pochodzenia” charakteryzuje nie tylko Jergovicia, ale i twórczość takich pisarzy jak Hemon, Saša Stanišić czy Igor Štiks.
} 
moją tożsamość? Powrót do przeszłości wynika jednocześnie - jak mi się wydaje z poczucia dojmującej straty, wynikającej „z trudnych wydarzeń historycznych, jakie dotknęły konkretnych osób i społeczności" 43 . Doświadczenie utraty domaga się mianowicie kompensacji. Opowieść o świecie utraconym, zakwestionowanie poglądów, które dowodzą, iż owa rzeczywistość nigdy nie istniała, reprezentowanie rzeczywistości za pośrednictwem języka, jej uobecnienie ma za zadanie w moim przekonaniu - poświadczyć jej istnienie, a zatem pośrednio ją przywrócić (nawet jeśli ma to miejsce jedynie na papierze).

Zabiegi mitologizacyjne, jakie odnaleźć można na wielu poziomach narracji Jergovicia, stają się sposobem na przezwyciężenie historii, co jest zgodne z rozpoznaniami badaczy kultur archaicznych ${ }^{44}$. Swoiście wykreowany mit czy po prostu osobista opowieść przeciwstawiana jest Historii, przekazowi oficjalnemu. Można by powiedzieć, że rzeczywistość jugosłowiańska jest w tych utworach obecna, nigdy jednak nie jest ona ważna dla bohaterów niejako sama w sobie, lecz raczej ze względu na konsekwencje, jakie ma dla ich młodzieńczych doświadczeń i osobistych przeżyć. Mamy zatem do czynienia ze swoistą prywatyzacją historii45, wy-

43 D. Lisak-Gębala, Literackie świadectwa kresowej melancholii, w: A. Małczyńska, B. Małczyński (red.), W kregu melancholii. Opole-Wrocław 2010, s. 101.

${ }^{44} \mathrm{Na}$ ten aspekt mitologizacji zwraca uwagę E. Wiegandt w swej rozprawie o micie Galicji w literaturze polskiej. Zob. E. Wiegandt, op. cit., s. 183. Badaczka w tym kontekście wymienia następujące aspekty mitu: przemiana przestrzeni historycznej w rodzinną, czyli w ojczyznę prywatną (wskutek sakralizacji historycznych form przestrzennych), która staje się przedmiotem kultu i nie podlega dziejowym zwrotom. Mit ojczyzny prywatnej przezwycięża wyobcowanie z historii i włącza jednostkę w pewną zbiorowość. Warto także podkreślić, że historyczny determinizm podlega wymianie na wieczne prawa religijno-moralne. Wygnanie z raju ojczyzny prywatnej jest karą za grzech naruszenia normy współżycia ludzi. Normę ową ludzie pogranicza spełniają lepiej od innych, ale i jaskrawiej ją przekraczają. Ich wina uświadamia zaś, że nacjonalizm jest najgorszym grzechem ludzkości. Zob. Ibidem, s, 183-184. Swoje rozważania Wiegandt opiera na analizach kultur tradycyjnych prezentowanych przez Mirceę Eliadego Zob. m. in. M. Eliade, Świat archaiczny wobec historii, w: Tegoż, Sacrum. Mit. Historia. Wybór esejów. Tłum. A. Tatarkiewicz. Wyboru dokonał M. Czerwiński. Wstępem opatrzył B. Moliński. Warszawa 1970, s. 249-290.

45 Terminu tego używa Czapliński pisząc o polskiej literaturze lat dziewięćdziesiątych w tekście Wznoszenie biografii, w: Tegoż, Wznioste tęsknoty..., op. cit., s. 15. Anisa Avdagić zaś w swoim artykule poświęconym opowiadaniu bośniackohercegowińskiemu zauważa, że w opowieściach Jergovicia bardzo silnie pobrzmiewa tradycyjne rozumienie domu, które połączone jest z nostalgicznym poczuciem solidarności lub smutku wywołanym nagłą i wymuszoną utratą poczucia przynależności. Podkreśla przy tym, że twórczość Jergovicia oraz Hemona pozbawiona jest nostalgii za historią. Zob. A. Avdagić, Bosanskohercegovačka pripovijetka u tranziciji: pozitivne subverzije, "Sarajevske sveske” 2010, nr 27-28, s. 261-262. Z kolei Alma Denić-Grabić twierdzi, skupiając swoją uwagę na powieści, ale konstatacje te, wg mnie, dotyczą w równym stopniu krótszych form prozatorskich, że głos narratora, który pojawia się $\mathrm{w}$ utworach pisarzy z Bośni i Hercegowiny w formie skargi, poprzez opis pewnego intymnego świata $\mathrm{w}$ formie "małych" opowieści, mówi w imieniu tych, którzy mówić już nie mogą i odkrywa zgubne konsekwencje wojny. Wyraźną w tej prozie nieufność wobec wielkich narracji oraz skupienie swej uwagi na dyskursywnej różnorodności osobistych opowieści autorka łączy z obecno- 
niesieniem do rangi depozytariusza prawdy pamięci prywatnej kosztem oficjalnej historii oraz uruchomieniem mechanizmu nostalgii, którego specyfikę opisuje P. Czapliński, twierdząc, że „pozbawia [ona - S.G.] historię ciągłości i aksjologicznej obiektywności, wyjmując wydarzenia z kontekstu i postępując z nimi według praw serca, a nie rozumu" 46 . Natomiast Maria Delaperrière zauważa, że: „To nowe «usubiektywnianie» Historii nie jest jednak pozbawione ironii, która zazwyczaj [...] łączy się z poczuciem niemożności uchwycenia rzeczywistości historycznej" ${ }^{47}$. Wydaje się, że w przypadku Bośniaków o ironii w znacznej mierze decyduje także fakt skompromitowania się ideału wspólnoty (rozumianej w sensie narodowym) i wiedza o tym wszystkim, co przyniosły zmitologizowane wizje braterstwa i jedności narodów Jugosławii, które następnie przekształciły się w ksenofobiczne koncepcje narodowe. Warto wspomnieć, że odwrotnie sprawa ma się ze wspólnotą kulturową. Ona to bowiem wydaje się być utraconym, często współcześnie przywoływanym, nawet jeśli nie ideałem, to wartością zdecydowanie pozytywną ${ }^{48}$. W literaturze tej jednak, obok aspektu idealizującego i pierwiastka nostalgicznego (wyrażonego wprost chociażby przez Jergovicia ${ }^{49}$ ), silnie obecna jest ironia, która prozę nostalgiczną (zasklepioną $\mathrm{w}$ pewnych kliszach wyobrażeniowych i stałych wartościach estetycznych), stanowiącą według Czaplińskiego przykład „komunikacji łatwej"50, w zdecydowany sposób łagodzi ${ }^{51}$. Wydaje się, że wynika ona z uświadamianego i wyartykułowanego dystansu twórców wobec świata ich mło-

ścią w tej twórczości refleksji postmodernistycznej. Zob. A. Denić-Grabić, Kraj dvadesetog stoljeća: bosanskohercegovački roman između globalnog i lokalnog, w: Ibidem, s. 286-287.

46 P. Czapliński, Wznoszenie..., op. cit., s. 27.

47 M. Dellapière, Historia w polskiej literaturze wspótczesnej. Gry i dekonstrukcje, w: Tejże, Pod znakiem antynomii. Studia i szkice o polskiej literaturze XX wieku. Kraków 2006, s. 118.

${ }^{48}$ Najlepszym przykładem będzie tutaj twórczość pisarzy nazywanych jugonostalgikami, których najczęściej przywoływaną (czasem aprobatywnie, lecz w przeważającej liczbie przypadków negatywnie ocenianą, zwłaszcza przez propagatorów wizji wspólnot czystych narodowo... i kulturowo) przedstawicielką jest D. Ugrešić.

49 „Od najmłodszych lat byłem okropnie nostalgiczny. Właściwie nostalgia pojawiła się, gdy zacząłem mieć co wspominać. Wczoraj zawsze było dla mnie lepsze niż dziš”. („Od najmanjih sam nogu bio užasno nostalgičan. Zapravo, nostalgija me počela hvatati čim sam se imao čega sjećati. Jučer je uvijek ostajalo boljim od danas"). M. Jergović, Historijska čitanka, op. cit., s. 12.

${ }^{50}$ Czapliński konstatuje: „(...) dla nostalgika waga przeszłości nie tkwi w obiektywnej randze doświadczeń i przemyśleń, lecz i ich jednostkowej niepowtarzalności (...). Dlatego proza nostalgiczna to z perspektywy ludzkiej oferta komunikacji szczerej, z perspektywy literackiej - oferta komunikacji łatwej. Wspomnienia są tedy prawie zawsze narażone na zarzut błahości, banalności, czy pretensjonalności (...). P. Czapliński, Wznoszenie..., op. cit., s. 21.

${ }^{51}$ Dobrawa Lisak-Gębala rozważając specyfikę twórczości Tadeusza Konwickiego zauważa, iż jego utwory, te wydawane oficjalnie, jak i w "drugim obiegu” określa „melancholia przemieszana $\mathrm{z}$ autoironiczną grą z własnym życiorysem (...). Przyjęta przez pisarza konwencja sprawdziła się (...) jako unikanie petryfikowania kresowej arkadii" D. Lisak-Gębala, op. cit., s. 109. Słowa te można odnieść także do twórczości pisarzy bośniackich. 
dości, w którym z oddalenia zarówno przestrzennego, jak i czasowego dostrzegają rys tragikomiczny. Humor, ironia czy wręcz groteska pojawiająca się w autobiograficznej prozie np. Jergovicia może wynikać także $\mathrm{z}$ ich niechęci wobec patosu, ale i niechęci wobec jednoznaczności. Jednoznaczności, która - jak mi się wydaje - cechuje wszelkiego rodzaju projekty "totalne”, takie chociażby jak: wizja bezkonfliktowej wspólnoty jugosłowiańskiej, wizja spełnionego tysiącletniego snu o niezależnej Chorwacji, jednostronna wizja historii czy w końcu idea powieści, w której dominuje jedna kategoria estetyczno-filozoficzna.

Skoro $\mathrm{w}$ konfrontacji z upadkiem wielkich narracji należy odnaleźć siebie (zrekonstruować/zdekonstruować własną tożsamość), to naturalny wydaje się powrót do przeszłości i jej swoiste przewartościowanie. Jak pisze Wiera Agiejewa (w odniesieniu do literatury ukraińskiej) „pamięć historyczna często konkretyzuje się poprzez sięganie do przekazów rodzinnych, osobistych wspomnieńn ${ }^{52}$. Dokładnie takie same zjawisko obserwować możemy w literaturze pisarzy młodszej generacji z byłych republik Jugosławii. Można nawet uznać, że powrót do przeszłości i korzeni szczególnie obecny jest u twórców pochodzących z Bośni, choć też i pisarzy z innych krajów powstałych po rozpadzie państwa, których cechą charakterystyczną jest ich ambiwalentna natura, mieszana przynależność (casus Jergovicia, ale w pewnym sensie i Chorwatki Dašy Drndić czy Serba Davida Albahariego). Powrót do przeszłości może być w tych przypadkach rozumiany jako odpowiedź - może nawet nie do końca uświadomiona - skierowana do tych, którzy arbitralnie podważają przynależność jednostki do „oczyszczonej” wspólnoty, sytuują ją poza jej ramami.

I chociaż Sarajewo takie, jakie opisuje chociażby Jergović dziś już nie istnieje w przestrzeni realnej, to funkcjonuje we wspomnieniach i w... Internecie. Autor zauważa, że miasto, o którym opowiada w imię prawa do własnych wspomnien, subiektywnych iluzji i pokoleniowych mitów istnieje $\mathrm{w}$ przestrzeni wirtualnej, tworzonej przez tych wszystkich mieszkańców Sarajewa, którzy żyją dziś w Montrealu, Ottawie, Phoenix ${ }^{53}$ zaświadczając, że to wypełnione znaczeniami miejsce "żyło" kiedyś naprawdę.

Jergović w nostalgicznym nurcie swego pisarstwa, do którego zaliczyć można analizowany tutaj zbiór, tworzy mitologię, w której nakładają się na siebie i wzajemnie oświetlają trzy elementy: ten dotyczący indywidualnej biografii, rodziny (w tym wypadku przodków i całego rodu) oraz mit kulturowy (dotykający losów i specyfiki pewnej społeczności) ${ }^{54}$. Nora stawiając tezę, iż współcześnie tradycyjna

52 W. Agiejewa, Między autentyzmem a imitacja. Tłum.. B. Nazaruk, w: H. Janaszek-Ivaničkova (red.), Literatury słowiańskie po roku 1989. Nowe zjawiska, tendencje, perspektywy, T. 1, Transformacje. Warszawa 200, s. 157.

53 M. Jergović, Historijska čitanka, op. cit., s. 215.

$54 \mathrm{O}$ tych trzech mitach: indywidualnym, rodzinnym i kulturowym pisze Wiegandt analizując twórczość A. Kuśniewicza. Zob. A. Wiegandt, op. cit., s. 84. Wydaje mi się także, że zabiegi służące 
pamięć zanika, jednocześnie zauważa tendencję do „kolekcjonowania pozostałości, świadectw, dokumentów, obrazów, pogłosek, jakichkolwiek widzialnych znaków tego, co było, tak jakby to pęczniejące dossier miało być wykorzystane jako dowód przez nieznanym trybunałem historii" 55 . Ślady przeszłości, które z takim zapamiętaniem kolekcjonuje chociażby Jergović, rzeczywiście stanowią swoisty dowód $\mathrm{w}$ sporze $\mathrm{z}$ przedstawicielami nowej wersji historii. Biorąc $\mathrm{z}$ kolei pod uwagę zarówno analizowany tu zbiór, jak również twórczość pisarzy przywoływanych tu tylko z nazwiska, trudno $\mathrm{w}$ zupełności zgodzić się z tezami francuskiego badacza ${ }^{56}$. Literatura bośniacka, w pewnym swym nurcie oczywiście, jawnie przeczy przekonaniu o dokonującym się obecnie procesie zapominania, a zarazem dowodzi, że przedmioty (ale i doświadczenia), których trwanie - wydawać by się mogło - bezpowrotnie się skończyło powracają do współczesności, uzyskując nowe znaczenia. Analizowana twórczość Jergovicia ujawnia zaś „specyficzny dla nowoczesnej podmiotowości stan braku stabilizacji, stan kryzysu i zagrożenia [...], wynikający z utraty obiektywnych ram egzystencji, dawnych mitów zakwestionowanych w trakcie procesów modernizacyjnych"57. Taka „zagubiona" podmiotowość ponownie kształtuje się za sprawą pamięci i odtwarzania elementów składających się na rzeczywistość minioną i utraconą.

mitologizacji są w swych najgłębszych podstawach zawsze takie same, dlatego też wiele $\mathrm{z}$ tez stawianych przez autorkę rozprawy o micie Galicji można by wykorzystać w analizie obrazu Sarajewa, jaki wyłania się z kart utworów Jergovicia.

55 P. Nora, op. cit., s. 7.

56 Z tezami Nory (oraz innych badaczy wieszczących kres pamięci) polemizuje Alida Assmann, wskazując na fakt, iż wraz z odchodzeniem bezpośrednich świadków Holokaustu nie dokonuje się proces zapominania, ma raczej miejsce proces odwrotny, którego bezpośrednim rezultatem jest „eskalacja zagadnienia pamięci". Zob. A. Assmann, op. cit., s. 101-142.

57 M. Kuziak, Ślad Mickiewicza, w: M. Cieśla-Korytkowska, I. Puchalska, M. Siwiec (red.), Oblicza Narcyza: obecność autora w dziele. Kraków 2008, s. 99. 